\title{
Persepsi Keterancaman, Fundamentalisme dan Kebencian terhadap Intoleransi Politik
}

\author{
Muhammad Nur Rifqi Fuadi 1, Gazi Saloom ${ }^{1}$ \\ ${ }^{1}$ Fakultas Psikologi UIN Syarif Hidayatullah Jakarta
}

DOI: http://doi.org/10.29080/jpp.v11i2.428

\begin{abstract}
Implementing a democratic system in Indonesia to have justice has not come to have a light yet. It was shown from the democracy index declined and intolerance increased in the past four years. This research aims to study the effect of threat perception, fundamentalism, and hatred on political intolerance. Having 361 students of UIN Syarif Hidayatullah Jakarta, this research uses purposive technique sampling. Data were analyzed using multiple regression with SPSS. The results showed that there was a significant effect with 10,8\% contribution of threat perception, fundamentalism, and hatred on political intolerance. Meanwhile, a realistic threat was the only aspect of having a significant effect on political intolerance.
\end{abstract}

Keywords : Political Intolerance, Perception of Threat, Fundamentalism, Hatred

\begin{abstract}
Abstrak : Adanya keinginan untuk mencapai keadilan bersama dengan menerapkan sistem demokrasi di Indonesia, nampaknya belum mencapai titik terang. Hal ini terlihat dari menurunnya indeks demokrasi di Indonesia serta meningkatnya sikap intoleransi empat tahun ke-belakang. Penelitian ini bertujuan untuk melihat pengaruh persepsi keterancaman, fundamentalisme dan kebencian terhadap intoleransi politik. Penelitian ini dilakukan pada 361 mahasiswa UIN Syarif Hidayatullah Jakarta dengan menggunakan teknik non-probability sampling, yakni dengan menggunakan purposive sampling. Analisis data dilakukan dengan menggunakan metode analisis regresi berganda dengan bantuan software SPSS. Hasil penelitian menunjukkan bawa terdapat pengaruh yang signifikan persepsi keterancaman, fundamentalisme dan kebencian terhadap intoleransi politik dengan kontribusi sebesar 10,8 \%. Adapun apabila melihat koefisien regresi dari masing-masing independent variable, hanya aspek realistic threat yang berpengaruh signifikan terhadap intoleransi politik.
\end{abstract}

Kata kunci : Intoleransi Politik, Persepsi Keterancaman, Fundamentalisme, Kebencian 


\section{Pendahuluan}

Penelitian yang dilakukan oleh LIPI menyebutkan intoleransi politik di Indonesia cukup tinggi (Wardah, 2018). Bahkan tercatat indeks demokrasi indonesia (IDI) 2016 mencapai 70,09 dalam skala 0 sampai 100. Capaian kinerja demokrasi Indonesia ini masih berada pada kategori "sedang". Angka ini mengalami penurunan dibandingkan dengan angka IDI 2015 yang mencapai 72,82 (Rinaldi, 2018). Peningkatan sikap intoleran juga terlihat dari survei The Wahid yang mencatat pada tahun 2016, mayoritas muslim laki-laki ataupun perempuan bersikap intoleran terhadap kelompok yang tidak disukai sebesar 51\%. Survei tersebut diikuti dengan survei terbaru pada tahun 2017, dimana sikap intoleransi meningkat menjadi 57,1\% (Wahid \& LSI, 2018). Secara politik kebanyakan warga muslim (lebih dari 50\%) merasa kebaratan jika kelompok lain dalam hal ini nonmuslim secara keseluruhan menjadi kepala pemerintahan di tingkat bupati/ wali kota, gubernur, wakil presiden, dan presiden (LSI, 2019).

Intoleransi politik dipandang sebagai tidak adanya kesadaran untuk memberikan penilaian dan penerimaan yang baik terhadap orang lain yang berbeda melibatkan prinsip keadilan (fairness), rasionalitas (reasonableness), kepedulian (empathy) (Witenberg, 2019). Gibson, (1988) mendefinisikan intoleransi politik sebagai sikap individu untuk tidak menerima kebebasan politik terhadap individu atau kelompok lain yang secara politik dianggap berbeda. Intoleransi politik juga bisa dipahami sebagai bentuk keengganan untuk menerima gagasan dan pandangan dari kelompok yang tidak disukai (J. L. Gibson, 2007). Hal itu mengisyaratkan tidak adanya keinginan untuk memperbolehkan segala ekspresi dari ide-ide yang bertentangan dengannya. Oleh karena itu, hal ini sangat jauh dengan prinsip toleransi politik dalam demokrasi yang mengharuskan semua ide-ide dan gagasan mendapatkan akses yang sama dan sebebas-bebasnya disampaikan sesuai dengan hukum yang berlaku (J. L. Gibson, 2007).

Intoleransi politik dipengaruhi banyak faktor. Salah satu faktor yang mempengaruhinya adalah perception of threat (J. Gibson et al., 2019; Hodson, 2011; Halperin et al., 2009) . Ancaman ini fokus pada kelompok yang tidak disukai serta dirasa mengancam terhadap individu. Tidak terbangunnya budaya komunikasi atau istilah yang dibuat Hodson adalah "kontak" antara Individu membuat perasaan ancaman semakin terasa. Ketika orang merasa terancam, mereka sering merespons dengan menjadi lebih percaya diri dan lebih defensive terhadap keyakinan mereka sebelumnya, lebih berpikiran tertutup, dan lebih agresif terhadap mereka yang tidak setuju dengan mereka (Haas \& Cunningham, 2014). Untuk memahami persepsi ancaman secara komprehensif, W. G. Stephan dan Stephan (dalam Riek et al., 2006) mengusulkan Integrated Threat Theory (ITT), yang mengklasifikasikan ancaman menjadi empat jenis meliputi: realistic threat, symbolic threat, intergroup anxiety, dan negative stereotypes.

Menurut (Renfro, Duran, Stephan, \& Clason, 2006) realistic threat merupakan bentuk acaman yang berkaitan dengan kekuasan politik, ekonomi, sumber daya dan kesejahteraan umum yang dirasakan oleh suatu kelompok. Termasuk ancaman yang menyangkut kerugian fisik dan material terhadap anggota kelompok individu seperti rasa sakit akibat penyiksaan atau kematian, juga sebagai kerugian ekonomi, perampasan sumber daya bernilai, dan ancaman terhadap kesehatan atau keamanan pribadi. Symbolic threat dipahami sebagai bentuk ancaman yang tampak akibat adanya perbedaan norma, nilai, moral dan keyakinan, falsafah dan cara pandang terhadap dunia diantara kelompok yang satu dengan yang lainnya. Intergroup anxiety merupakan bentuk ancaman yang muncul pada saat angggota suatu kelompok merasa takut terhadap akibat negatif yang akan dirasakan saat melakukan interaksi dengan kelompok lain. Ancaman yang dirasakan memiliki konsekuensi nyata terlepas apakah persepsi ancaman itu akurat atau tidak. Negative stereotype merupakan bentuk ancaman akibat adanya stereotip negatif yang menempel pada individu atau kelompok. Seseorang percaya bahwa individu yang 
memiliki stereotip negatif akan berperilaku negatif sesuai dengan stereotip yang menempel pada dirinya.

Faktor lain yang juga mempengaruhi intoleransi politik adalah fundamentalism (Barkun, 2003; Newheiser et al., 2013). Lembaga survei juga menyatakan bahwa meningkatnya jumlah intoleransi di Indonesia memiliki kaitan erat dengan gelombang fundamentalisme yang melanda Indonesia (Assyaukanie, 2018). Newheiser et al., (2013) menyebutkan bahwa secara konsisten fundamentalisme agama berhubungan negatif dengan agama sebagai quest (orientasi pencarian). Seseorang dengan orientasi pencarian cenderung kritis sehingga tidak akan menganggap agama sebagai sesuatu yang final dan paripurna. Hubungan negatif membuat kita bisa memahami bahwa semakin fundamental seseorang maka semakin hilang jiwa kritis dan cenderung menganggap agama sebagai sesuatu yang final.

Koopmans, (2015) melihat fundamentalisme sebagai tiga sikap yang saling berkaitan, yaitu bahwa orang yang mempunyai keyakinan harus kembali kepada aturan yang sudah ditetapkan di masa lalu yang bersifat kekal dan tidak dapat diubah, bahwa aturan-aturan yang ada hanya diizinkan untuk satu penafsiran saja dan mengikat orangorang yang memeluk kepercayaan tersebut, dan bahwa aturan agama harus mendapat prioritas di atas hukum sekuler bagi orang-orang yang mempercayai agama tersebut. Menurut Hood, Hill dan Williamsons (dalam Agustin, 2017) adanya fundamentalisme agama tidak hanya sekedar diikuti keyakinan yang kuat, akan tetapi hal yang paling mendasar adalah bagaimana keyakinan tersebut dimaknai dan dipahami. Ini sangat erat kaitannya dengan metode seseorang dalam mengkaji kitab sucinya. Metode inilah yang kemudian membentuk fundamentalisme agama yang memahami kitab suci secara literal, sehingga oleh Hood et all disebut sebagai model intratekstual.

Selain itu, studi lain menunjukan hatred juga merupakan faktor yang mempengaruhi intoleransi politik. Penelitian yang dilakukan oleh Halperin et al., (2009) menunjukan bahwa hatred merupakan prediktor intoleransi yang sangat baik. Dalam penelitiannya hatred disandingkan dengan emosi negatif lain yaitu fear dan anger, namun keduanya tidak menunjukan pengaruhnya kecuali dimediasi oleh hatred. Adanya hatred mendorong seseorang untuk berbuat jahat, menghapuskan dan bahkan menghilangkan individu atau kelompok diluarnya (Halperin, 2008). Bahkan dalam penelitian, adanya dukungan aksi ekstrim militer yang dilakukan oleh kaum yahudi yang berada di Israel terhadap Palestina adalah bentuk sentiment hatred yang meningkat (Halperin et al., 2010).

Untuk mengetahui hatred, Halperin et al., (2012) mengemukakan bahwa terdapat dua bentuk hatred, berkaitan namun berbeda. Bentuk pertama adalah sentimental, stabil, familiar dan akrab dengan "membenci". Perasaan emosional yang bersifat berkelanjutan serta sepenuhnya menolak anggota kelompok diluarnya. Bentuk ini disebut sebagai chronic hatred. Bentuk kedua adalah emosional, kuat dan "berkobar". Perasaan negatif yang parah, ekstrem dan singkat, yang ditujukan kepada kelompok luar dan anggotaanggotanya dalam menanggapi insiden tertentu yang dianggap sebagai pelanggaran berat dan signifikan terhadap kelompok atau anggotanya. Perasaan yang parah ini sering disertai dengan gejala fisik yang tidak menyenangkan dan rasa tidak berdaya. Bentuk ini kita kenal sebagai immediate hatred. 2 bentuk hatred ini dapat menyasar kepada individu maupun kelompok.

Kondisi intoleransi politik di Indonesia masih perlu untuk diteliti karena hasil survei panjang pada tahun 2016 hingga 2019 yang dilakukan oleh Wahid Institute dan LSI menunjukkan peningkatan yang terus terjadi. Stereotip negatif yang beredar di masyarakat juga menghasilkan ancaman dengan ekspektasi negatif terhadap perilaku individu atau kelompok luar. Jika tidak dicarikan sejumlah solusi untuk menangani masalah intoleransi politik ini maka dikhawatirkan sejumlah jiwa yang tertutup akan menjadi individu yang intoleran terhadap apa yang ada diluar keyakinannya. Perasaan 
negatif serta persepsi kognitif bahwa anggota kelompok yang dibenci akan menyebabkan pelanggaran dengan cara yang parah, dan akan berulang dengan disengaja. Berdasarkan pemaparan di atas, maka penelitian ini akan melihat pengaruh perception of threat, fundamentalism dan hatred terhadap intoleransi politik.

\section{Metode Penelitian}

Penelitian ini menggunakan metode kuantitatif korelasional. Populasi penelitian adalah mahasiswa UIN Syarif Hidayatullah Jakarta dengan melibatkan 361 partisipan sebagai sampel. Jumlah partisipan laki-laki sebanyak 122 dan perempuan berjumlah 239 . Partisipan yang non-asrama lebih banyak (65,38 \%) dibanding yang berasrama $(34,62 \%)$. Pengambilan sampel menggunakan purposive tehnik sampling, yaitu mereka yang mempunyai kriteria yang sudah ditetapkan oleh peneliti. Analisis data yang digunakan adalah mulitiple regression dengan SPSS. Peneliti melakukan uji validitas terlebih dahulu pada masing-masing alat ukur dengan menggunakan confirmatory factor analysis (CFA) dengan bantuan software LISREL.

Adapun tiga alat ukur yang digunakan dalam penelitian. Alat ukur intoleransi politik yang digunakan merupakan hasil pengembangan yang dilakukan oleh Putra, Idhamsyah E. (2007) berdasarkan teori yang dikemukakan oleh J. L. Gibson, (1988). Jumlah butir item dalam alat ukur ini adalah lima item. Untuk alat ukur perception of threat peneliti menggunakan integreted threat scale dari Stephan et al., (2000) yang dikembangkan oleh Lusiana (2004). Terdapat empat dimensi ancaman di dalamnya yaitu realistic threat, symbolic threat, intergroup anxiety dan negative stereotypes. Adapun alat ukur fundamentalism berdasarkan hasil adaptasi yang dilakukan oleh Agustin (2017) berdasarkan teori fundamentalism dari Koopmans, (2015). Terdapat tiga indikator dalam mengukur fundamentalism yaitu ketika individu yang memeluk kepercayaan tertentu maka ia memutuskan kembali kepada aturan yang kekal, meyakini aturan-aturan yang abadi hanya memiliki satu penafsiran dan meyakini bahwa aturan agama harus mendapat prioritas di atas hukum sekuler. Terakhir, alat ukur hatred merupakan hasil adaptasi peneliti pada construction of hatred scale dari Halperin et al., (2012). Dalam alat ukur ini terdapat dua dimensi yaitu cronic hatred dan immediate hatred. Secara keseluruhan alat ukur penelitian ini menggunakan skala likert dengan pilihan sangat tidak setuju hingga sangat setuju.

\section{Hasil Penelitian}

Hasil penelitian pertama yang ditampilkan adalah nilai $\mathrm{R}$ Square untuk mengetahui persentase (\%) varians dependent variable yang dijelaskan oleh independent variable. Adapun hasilnya dapat dilihat pada tabel 1 di bawah ini.

Tabel 1

R Square

\begin{tabular}{|c|c|c|c|c|}
\hline Model & $\mathrm{R}$ & R Square & Adjusted R Square & Std. Error of the Estimate \\
\hline 1 & $.328^{a}$ & .108 & .090 & 8.44496 \\
\hline
\end{tabular}

Pada tabel 1 di atas dapat dilihat bahwa diperoleh R-Square sebesar 0,108 atau $10,8 \%$. Artinya sebesar 10,8 \% variasi dari sikap intoleransi politik dapat dijelaskan oleh variasi seluruh independent variable (realistic, symbolic, intergroup, negative, fundamental, cronic dan immediate). Adapun $89,2 \%$ sisanya dipengaruhi oleh variabel lain diluar penelitian ini. 
Hasil penelitian kedua adalah menjawab pertanyaan apakah seluruh independent variable memiliki pengaruh yang signifikan terhadap sikap intoleransi politik. Hasil Uji $\mathrm{F}$ dapat dilihat pada tabel 2 di bawah ini:

Tabel 2

Signifikansi Hasil Analisis Regresi

\begin{tabular}{crrrrr}
\hline Model & Sum of Squares & \multicolumn{1}{c}{ Df } & Mean Square & F & Sig \\
\hline 1 Regresion & 3034.515 & 7 & 433.502 & 6.078 & $.000^{\mathrm{a}}$ \\
Residual & 25175.028 & 353 & 71.317 & & \\
Total & 28209.543 & 360 & & & \\
\hline
\end{tabular}

a. Predictors: (constant), immediate, fundamental, intergroup, negative, cronic, realistic, symbolic.

b. Dependent Variable: Intoleransi

Berdasarkan Uji F pada tabel 2 di atas dapat dilihat bahwa nilai sig<0,05 yaitu 0,000. Ini menunjukan bahwa hipotesis nihil yang berbunyi "tidak ada pengaruh yang signifikan realistic, symbolic, intergroup, negative, fundamental, cronic dan immediate terhadap intoleransi politik" ditolak. Artinya ada pengaruh yang signifikan realistic, symbolic, intergroup, negative, fundamental, cronic dan immediate terhadap intoleransi politik.

Hasil penelitian ketiga adalah koefisien regresi dari masing-masing independent variable. Apabila nilai sig $<0,05$ maka koefisien regresi tersebut signifikan. Ini berarti independent variable tersebut memiliki pengaruh yang signifikan terhadap intoleransi politik. Adapun besarnya koefisien regresi dari masing-masing independent variable bisa dilihat pada tabel 3 di bawah ini:

Tabel 3

Koefisien Regresi

\begin{tabular}{|c|c|c|c|c|c|c|}
\hline \multirow{2}{*}{\multicolumn{2}{|c|}{ model }} & \multicolumn{5}{|c|}{ Standardized } \\
\hline & & $\mathrm{B}$ & Std.Error & $\frac{\text { Coefficients }}{\text { Beta }}$ & $\mathrm{t}$ & $\operatorname{sig}$ \\
\hline \multirow{6}{*}{1} & Realistic & .211 & .074 & .231 & 2.863 & .004 \\
\hline & Symbolic & -.080 & .078 & -.087 & -1.034 & .302 \\
\hline & Intergroup & .020 & .055 & .021 & .354 & .724 \\
\hline & Fundamental & .003 & .050 & .003 & .054 & .957 \\
\hline & Cronic & .077 & .072 & .081 & 1.065 & .288 \\
\hline & Immediate & .091 & .056 & .099 & 1.619 & .106 \\
\hline
\end{tabular}

a. Dependent Variable: Intoleransi

Berdasarkan tabel 3 di atas dapat disimpulkan bahwa persamaan regresinya adalah sebagai berikut:

\section{Intoleransi $=31.892+0,211 *$ Realistic $-0,080 *$ Symbolic $+0,020 *$ Intergroup + $0,041 *$ Negative $+0,003 *$ Fundamental $+0,077 *$ Cronic $+0,091 *$ Immediate}

Dari persamaan regresi tersebut, dapat diketahui bahwa hanya realistic threat saja yang mempunyai pengaruh signifikan terhadap intoleransi politik. Adapun enam variabel lain tidak berpengaruh signifikan.

\section{Pembahasan}

Hasil penelitian menunjukan ada pengaruh yang signifikan realistic, symbolic, intergroup, negative, fundamental, cronic dan immediate terhadap intoleransi politik. Walaupun sumbangannya terlampau kecil yaitu 10,8 \% intoleransi politik dipengaruhi 
oleh independent variable penelitian ini. Selebihnya, sebanyak 89,2 \% intoleransi dipengaruhi oleh variabel lain diluar penelitian ini. Dari hasil masing-masing variabel, hanya aspek realistic threat pada variabel perception of threat yang mempunyai pengaruh signifikan dan positif terhadap intoleransi politik. Ini artinya ketika realistic threat meningkat maka intoleransi politik pun meningkat, pun sebaliknya. Hal ini, sesuai dengan pernyataan Alport tentang sikap intoleransi yang muncul saat seseorang merasa terancam (Hodson, 2011). Namun, ancaman yang dirasakan disini masih pada ranah ancaman realistis. Ancaman ini berkaitan dengan kekuasaan politik, ekonomi (termasuk didalamnya keberpihakan prioritas lapangan pekerjaan), sumber daya, kesejahteraan umum yang dirasakan serta kerugian fisik dan material yang dirasakan individu (Riek et al., 2006). Sehingga aspek realistic threat ini berpengaruh signifikan terhadap intoleransi politik.

Berbeda dengan aspek lain dari perception of threat, justru menunjukan tidak ada pengaruh signifikan terhadap intoleransi politik. Symbolic threat misalnya, ancaman yang berkaitan dengan perbedaan norma, nilai, moral dan keyakinan, falsafah dan cara pandang terhadap dunia justru menunjukan tidak berpengaruh signifikan terhadap intoleransi politik. Hal ini berbeda dengan penelitian Lusiana (2004) yang menunjukan adanya pengaruh terhadap intoleransi politik. Tidak ada pengaruh serta responden yang dominan pada kategori rendah, menunjukan tidak terjadi ancaman yang bersifat simbolis, sehingga tidak ada alasan untuk bersikap intoleran dengan alasan tersebut.

Aspek intergroup anxiety pada variabel perception of threat juga menunjukan hasil yang berbeda dengan hipotesis awal dalam penelitian ini. Hasil menunjukan bahwa tidak ada pengaruh intergroup anxiety terhadap intoleransi politik. Melihat tingkat intergroup anxiety yang paling dominan berada pada kategori tinggi, maka kecemasan antar kelompok dirasakan secara dominan oleh mahasiswa UIN Syarif Hidayatullah Jakarta. Namun, tidak lantas menjadikan berpengaruh secara signifikan terhadap intoleransi politik. Mengingat juga dalam intergroup anxiety nilai $\mathrm{R}^{2}$ Change sebesar 0,003 atau hanya memberikan kontribusi sebesar $0,3 \%$ (tidak signifikan) terhadap intoleransi politik.

Adapun aspek terakhir dari perception of threat adalah negative stereotypes. Hasil akhir penelitian ini menunjukan tidak ada pengaruh yang signifikan terhadap intoleransi politik. Rendahnya dominansi sampel penelitian yang merasakan negative stereotypes juga dimungkinkan menjadi pemicu tidak signifikannya penelitian ini. Ini artinya, tidak adanya ancaman yang diciptakan oleh ekspektasi negatif terhadap perilaku individu luar. Begitupun dengan variabel fundamentalism yang menunjukan tidak ada pengaruh signifikan terhadap intoleransi politik. Pada penelitian Barkun, (2003), fundamentalism dianggap sebagai penyebab adanya persepsi ancaman dan adanya asosiasi negatif akan posisi agama yang berubah menjadi kekuatan gelap. Adapun dalam penelitian ini, fundamentalism terbatas pada sikap beragama mahasiswa UIN Syarif Hidayatullah Jakarta yang ingin kembali pada aturan agama islam, menginginkan sumber hukum islam yaitu alqur'an mempunyai satu penafsiran, serta memilih aturan al-qur'an di atas peraturan lain, sesuai dengan yang dikatakan Koopmans, (2015). Wajar saja dalam penelitian ini menunjukan tidak ada pengaruh yang signifikan, sama hal nya dengan hasil penelitian Sihombing, Chusniya \& Shanti (2016). Hasil penelitian ini juga sesuai dengan penelitian Putra, Idhamsyah. E (2007), dimana fundamentalism tidak bisa berpengaruh secara langsung terhadap intoleransi politik, kecuali dimediasi dengan orientasi dominasi sosial.

Temuan selanjutnya menunjukan tidak ada pengaruh yang signifikan hatred (cronic hatred dan immediate hatred) terhadap intoleransi politik. Memang sedari awal peneliti menyadari bahwa hatred merupakan emosi yang bukan standar, melainkan perasaan emosional akibat adanya persepsi pelanggaran atau tanggapan terhadap insiden tertentu yang dilakukan kelompok luar. Salah satu penyebab jarangnya konstruk hatred diminati untuk menjadi variabel penelitian adalah sampel penelitian yang dilakukan oleh Fischer et al., (2018) pun tidak pernah menunjukan hatred. Adanya dominasi kategorisasi 
sampel cronic hatred dan immediate hatred berada pada posisi rendah, menjadi salah satu sebab variabel hatred tidak berpengaruh terhadap intolerasi politik. Ditambah karakteristik sampel dalam penelitian sebelumnya menggunakan sampel yahudi Israel yang secara politik masih terus berseteru dengan Palestina. Berbeda dengan sampel dalam penelitian ini, menggunakan sampel mahasiswa UIN Syarif Hidayatullah Jakarta yang tidak mengalami persinggungan secara langsung dengan kelompok luar.

Hasil temuan dalam penelitian ini memberikan informasi bahwa masing-masing independent variable yang tidak memiliki pengaruh signifikan terhadap intoleransi politik, tidak lepas dari perbedaan sampel yang digunakan, perbedaan kondisi saat dilakukan penelitian (kebetulan penyebaran kuesioner dilakukan di saat bulan suci Ramadhan dan ditengah-tengah pandemi covid-19, sedangkan karakteristik kuesioner cenderung negatif) serta karakter budaya yang berbeda. Ditambah kondisi intoleransi politik di Indonesia menurut peneliti bersifat momentum. Terlihat dari sikap intoleransi politik yang dari tahun ke-tahun terus meningkat dan memuncak pada saat pilpres 2019 (LSI, 2019). Keterbatasan peneliti juga sangat mungkin sekali turut menjadi alasan adanya perbedaan dengan penelitian sebelumnya.

\section{Simpulan dan Saran}

Penelitian menyimpulkan bahwa terdapat pengaruh yang signifikan perception of threat, fundamentalism dan hatred terhadap intoleransi politik dengan kontribusi sebesar 10,8 \%. Jika dilihat dari sisi koefisien regresi dari masing-masing independent variable, dapat disimpulkan bahwa hanya aspek ancaman realistic (realistic threat) yang berpengaruh signifikan terhadap intoleransi politik.

Berdasarkan hasil penelitian, penulis menyarankan agar ke depan hasil riset ini dikonfirmasi dengan riset kualitatif, terutama untuk mengeksplorasi lebih dalam mengapa ancaman realistik berpengaruh signifikan terhadap intoleransi politik. Lebih jauh lagi, perlu diperdalam, apa bentuk ancaman realistik yang berpengaruh terhadap intoleransi politik.

\section{Daftar Pustaka}

Agustin, Trisiawani. (2017). Studi Tentang Prasangka Sosial Terhadap Non-Muslim Dikaji Dari Fundamentalisme, Identitas Sosial, dan Religiusitas pada Mahasiswa. Psikologi Uin Syarif Hidayatullah Jakarta.

Assyaukanie, L. Akar - Akar Legal Intoleransi dan Diskriminasi di Indonesia. Maarif Institute, Vol.13, No.2 - Desember 2018

Barkun, M. (2003). Religious violence and the myth of fundamentalism. Totalitarian Movements and Political Religions, 4(3), 55-70. https://doi.org/10.1080/14690760412331326230

Fischer, A., Halperin, E., Canetti, D., \& Jasini, A. (2018). Why We Hate. Emotion Review, 10(4), 309-320. https://doi.org/10.1177/1754073917751229

Gibson, J., Claassen, C., \& Barceló, J. (2019). Deplorables: Emotions, Political Sophistication, and Political Intolerance. American Politics Research, 1532673X1882086. https://doi.org/10.1177/1532673X18820864

Gibson, J. L. (1988). Political Intolerance and Political Repression During the McCarthy Red Scare. American Political Science Review, 82(2), 511-529. https://doi.org/10.2307/1957398

Gibson, J. L. (2007). Political Intolerance in the Context of Democratic Theory. Oxford University Press. https://doi.org/10.1093/oxfordhb/9780199270125.003.0017

Haas, I. J., \& Cunningham, W. A. (2014). The Uncertainty Paradox: Perceived Threat Moderates the Effect of Uncertainty on Political Tolerance: The Uncertainty 
Paradox. Political Psychology, 35(2), 291-302. https://doi.org/10.1111/pops.12035

Halperin, E. (2008). Group-based Hatred in Intractable Conflict in Israel. Journal of Conflict Resolution, 52(5), 713-736. https://doi.org/10.1177/0022002708314665

Halperin, E., Canetti, D., \& Kimhi, S. (2012). In Love With Hatred: Rethinking the Role Hatred Plays in Shaping Political Behavior1: ROLE OF HATRED IN SHAPING POLITICAL BEHAVIOR. Journal of Applied Social Psychology, 42(9), 2231-2256. https://doi.org/10.1111/j.1559-1816.2012.00938.x

Halperin, E., Canetti-Nisim, D., \& Hirsch-Hoefler, S. (2009). The Central Role of GroupBased Hatred as an Emotional Antecedent of Political Intolerance: Evidence from Israel. Political Psychology, 30(1), 93-123. https://doi.org/10.1111/j.14679221.2008.00682.x

Halperin, E., Sharvit, K., \& Gross, J. J. (2010). Emotion and Emotion Regulation in Intergroup Conflict. An Appraisal-Based Framework. 24.

Hodson, G. (2011). Do Ideologically Intolerant People Benefit From Intergroup Contact? Current Directions in Psychological Science, 20(3), 154-159. https://doi.org/10.1177/0963721411409025

Koopmans, R. (2015). Religious Fundamentalism and Hostility against Out-groups: A Comparison of Muslims and Christians in Western Europe. Journal of Ethnic and Migration Studies, 41(1), 33-57. https://doi.org/10.1080/1369183X.2014.935307

Lusiana, Yusida. (2004). Model Integrasi Intoleransi Politik: Pengaruh Faktor Kepribadian dan Persepsi ancaman. Psikologi Universitas Indonesia

LSI (2019). Tantangan Intoleransi dan Kebebasan Sipil Serta Modal Kerja Pada Periode Kedua Pemerintahan Joko Widodo.

Newheiser, A.-K., Hewstone, M., Voci, A., Schmid, K., Zick, A., \& Küpper, B. (2013). SocialPsychological Aspects of Religion and Prejudice: Evidence from Survey and Experimental Research. In S. Clarke, R. Powell, \& J. Savulescu (Eds.), Religion, Intolerance, and Conflict (pp. 107-125). Oxford University Press. https://doi.org/10.1093/acprof:oso/9780199640911.003.0006

Putra, Idhamsyah, Eka. (2007). Pengaruh Orientasi Keberagamaan, Ideologi Politik, Fundamentalisme, dan Orientasi Dominasi Sosial terhadap Intoleransi Politik. Psikologi Universitas Indonesia

Renfro, C. L., Duran, A., Stephan, W. G., \& Clason, D. L. (2006). The Role of Threat in Attitudes Toward Affirmative Action and Its Beneficiaries1: THREATS AND AFFIRMATIVE ACTION. Journal of Applied Social Psychology, 36(1), 41-74. https://doi.org/10.1111/j.0021-9029.2006.00003.x

Riek, B. M., Mania, E. W., \& Gaertner, S. L. (2006). Intergroup Threat and Outgroup Attitudes: A Meta-Analytic Review. Personality and Social Psychology Review, 10(4), 336-353. https://doi.org/10.1207/s15327957pspr1004_4

Rinaldi, Taufik. (2018). Naskah Rekomendasi Kebijakan: Strategi Penguatan Nilai dan Toleransi di Indonesia. Wahid Foundation.

Sihombing, Marvel M.A.A.N. Chusniya, Tutut \& Shanti, Pravvisi. (2016). Intoleransi Politik Pemuda Hindu di Bali : Fundamentalisme Agama dan Ajaran Ahimsa. Psikologi Universitas Negeri Malang.

Stephan, W. G., Diaz-Loving, R., \& Duran, A. (2000). Integrated Threat Theory and Intercultural Attitudes: Mexico and the United States. Journal of Cross-Cultural Psychology, 31(2), 240-249. https://doi.org/10.1177/0022022100031002006

Wahid Foundation \& LSI. (2018). Laporan Survei Nasional Tren Toleransi SosialKeagamaan di Kalangan Perempuan Muslim Indonesia. 
Wardah, Fathiyah. (2018). Dipetik jam 06.47 WIB, tanggal 21 desember 2019, dari https://www.voaindonesia.com/a/lipi-intoleransi-politik-di-indonesiameningkat/4687374.html

Witenberg, R. T. (2019). The Psychology of Tolerance: Conception and Development. Springer Singapore. https://doi.org/10.1007/978-981-13-3789-5 